\title{
Influence of physical characteristics of coralline turf on associated macrofaunal assemblages
}

\author{
Brendan P. Kelaher* \\ Centre for Research on Ecological Impacts of Coastal Cities, Marine Ecology Laboratories A11, University of Sydney, \\ New South Wales, 2006, Australia
}

\begin{abstract}
The influences of the physical structure of coralline algal turf on associated macrofaunal assemblages were examined on a rocky intertidal shore near Sydney, Australia. Patches of artificial turf were used in a field experiment to mimic the physical structure of natural coralline turf. After 2 and $4 \mathrm{mo}$, the macrofaunal assemblages in artificial turf were compared to those in natural coralline turf and several control treatments. The initial development of assemblages in artificial turf was different from that in natural coralline turf. After $4 \mathrm{mo}$, however, the composition of macrofauna did not differ between natural and artificial turf, although abundances of bivalves and amphipods were significantly greater in artificial turf. Because of the similarities between the macrofaunal assemblages in natural and artificial turf, it is clear that the physical structure of the habitat has a major influence on the biodiversity of these assemblages. Nevertheless, differences between assemblages in natural and artificial turf probably indicate either that there were artefacts associated with the artificial turf or that biological characteristics of coralline turf also contribute to the diversity and abundances of macrofauna.
\end{abstract}

KEY WORDS: Coralline turf · Habitat structure $\cdot$ Macrofauna $\cdot$ Rocky shore Resale or republication not permitted without written consent of the publisher

\section{INTRODUCTION}

Biogenic habitats, those created by living organisms, generally have strong influences on local biodiversity (see Jones et al. 1994, 1997 for review). The physical structure created by biogenic habitats usually changes local environmental conditions and thereby alters biotic interactions among resident organisms (see Bell et al. 1991 for review). In addition, properties associated with being a habitat created by living organisms (e.g. its value as a food resource; see Brawley 1992 for review) may also affect many ecological processes. Differences in either the physical or biological characteristics of biogenic habitats can therefore have major impacts on community structure (Williams \& Seed 1992, Knowles \& Bell 1998, Crooks \& Khim 1999).

${ }^{*}$ Present address: Department of Ecology and Evolution, Life Sciences Building, State Universaty of New York, Stony Brook, New York 11794, USA. E-mail: bkelaher@life.bio.sunysb.edu
Organisms that form mat-like biogenic habitats, such as mussel beds (see Seed 1996 for review), ascidians (Fielding et al. 1994), algal turf (Myers \& Southgate 1980, Dean \& Connell 1987a) and lichens (Healy 1996), are common on rocky intertidal shores. These habitats are generally associated with diverse and abundant macrofaunal assemblages (e.g. Tsuchiya \& Nishihira 1985, Dean \& Connell 1987a) and therefore make large contributions to the local biodiversity. In these habitats, physical characteristics are believed to have strong influences on the associated organisms because the mat-like structure traps sediment and organic material (Tsuchiya \& Nishihira 1985, Gibbons 1988) and provides a refuge from desiccation (Nixon et al. 1971, Gibbons 1988), predation (Coull \& Wells 1983, Dean \& Connell 1987c) and wave action (Dommasnes 1968, Whorff et al. 1995). Nevertheless, biological characteristics of these habitats may also be important. For example, organisms may exude chemicals that attract or repel larvae of marine invertebrates or stim- 
ulate settlement (see Underwood 1979, Pawlik 1990 for reviews), or filter-feeding organisms may consume settling larvae (Williams 1980, Andre \& Rosenberg 1991). In addition, these habitat-forming organisms may be a source of food (Brawley 1992) or detritus (Tsuchiya \& Nishihira 1985) or produce toxic chemicals (see Dean \& Connell 1987b).

Separating the relative importance of physical and biological characteristics of biogenic habitats on associated organisms has often been attempted by comparing assemblages of organisms in artificial structures that mimic natural habitats to the organisms in the natural habitats (Cummings \& Ruber 1987, Sogard 1989, Worthington \& Fairweather 1989, Edgar 1991, Crooks \& Khim 1999). These artificial mimics possess similar physical characteristics to the natural habitats, but because they are not alive, they do not exhibit any of the biological characteristics. Various types of mimics or artificial substrata have been used to test hypotheses about faunal assemblages associated with mat-like habitats on rocky intertidal shores (e.g. modified polypropylene rope, Dean \& Connell 1987b, Edgar 1991; bundles of polyvinyl chloride [PVC] twine, Schreider 1998; plastic sheet, Dean \& Connell 1987b; plastic pan scourers, Myers \& Southgate 1980, Gibbons 1988). In some cases, it has been shown that the composition of assemblages in artificial habitats does not differ significantly from those in natural habitats (e.g. Dean \& Connell 1987b), suggesting that the physical characteristics of the habitat are most important in structuring associated assemblages. More often than not, however, there are differences between the assemblages in natural and artificial habitats (e.g. Myers \& Southgate 1980, Edgar 1991). Interpreting these results is much more difficult because there are alternative explanations, other than just influences of biological characteristics of the habitat. For example, differences in macrofauna may be due to the materials used to construct habitat mimics or due to subtle differences in physical structure. Alternatively, differences may be due to historic processes, such as large recruitment events or disturbances, that occurred prior to deployment of the artificial habitat but that have lasting effects on natural assemblages. Although it may not be possible to control all of these factors, careful experimental design will eliminate some of this uncertainty.

This report describes experiments investigating the importance of physical characteristics of coralline algal turf on associated macrofaunal assemblages on rocky intertidal shores near Sydney, Australia. Turf-forming articulated coralline algae are a major component of algal assemblages on many rocky shores (e.g. Stewart 1982, Dye 1993, Chapman \& Underwood 1998, Akioka et al. 1999). The densely packed fronds of coralline turf provide habitat for extremely diverse macrofaunal assemblages (Hicks 1971, Akioka et al. 1999), which may contain in excess of 200000 animals $\mathrm{m}^{-2}$ (Brown \& Taylor 1999). In this study, the influence of physical characteristics of coralline turf on associated macrofaunal assemblages was tested by comparing the macrofauna associated with habitat mimics, natural turf and a set of procedural controls (see 'Materials and methods') using univariate and multivariate techniques. As it was not known how long it would take for assemblages to develop, the experiment was set up so that they could be sampled independently at 2 times.

\section{MATERIALS AND METHODS}

This study was done at the Cape Banks Scientific Marine Research Area on the northern headland of the entrance to Botany Bay, Sydney, Australia $\left(34^{\circ} 00^{\prime} \mathrm{S}\right.$, $151^{\circ} 15^{\prime} \mathrm{E}$; see Underwood et al. 1983, Fairweather \& Underwood 1991 for description). The experiment was set up in a $20 \times 5 \mathrm{~m}$ area of the rock platform that was between 0.45 and $0.55 \mathrm{~m}$ above Indian Low Water Springs (tidal datum for Sydney). This area had extensive mats of coralline algal turf, comprising predominantly Corallina officinalis Linnaeus, although Jania spp. Lamouroux and Amphiroa spp. Lamouroux were occasionally found. The turf was also associated with a diverse epiphytic assemblage (see Kelaher 2000 for a description).

Patches of artificial turf (manufactured by Grass Alternative) were used as a surrogate for natural coralline turf. The turf was made of bundles of 16 polypropylene strips, separated from each other by $6 \mathrm{~mm}$ and attached in regular rows $(10 \mathrm{~mm}$ apart) to a latex back. Each polypropylene strip was orangeybrown, $26 \mathrm{~mm}$ long and $1.5 \mathrm{~mm}$ wide. The artificial turf was considered a relatively good habitat mimic for coralline turf because it had similar mat-like structure and frond length, trapped sediment and was quickly colonised by epiphytes. Although the colour of the polypropylene differed from natural turf, several studies have shown that the colour of artificial structures mimicking coralline turf has little influence on associated fauna (Worthington \& Fairweather 1989, Kelaher 2000). For each patch, the artificial turf was glued to an aluminium sheet $(0.6 \mathrm{~mm}$ thick) for rigidity and attached to the rock platform by 3 stainless steel screws. For each patch, a circular clearing $15 \mathrm{~cm}$ in diameter $\left(177 \mathrm{~cm}^{2}\right)$ was made in a mat of natural coralline turf, and a similar-sized patch of artificial turf was attached to the cleared rock surface. Clearings were carefully made to minimise the gap between the edge of the artificial turf and the surrounding coralline algae.

Testing the hypotheses required that macrofaunal assemblages in natural coralline turf be compared to 
those in artificial turf. Any differences between macrofauna in these treatments may not simply be due to biological characteristics of coralline turf, but also to biological and environmental processes that influenced macrofauna in natural coralline turf prior to deployment of the artificial turf. To control for historical effects and the possibility that existing assemblages influence colonisation, a treatment was included where natural coralline turf was defaunated, so that there were no macrofaunal assemblages at the beginning of the experiment. To defaunate the turf, cores of rock with the intact coralline turf were drilled from the platform using a diamond-tipped corer. Each core was rinsed vigorously with running freshwater and carefully picked through with forceps to remove any obvious remaining animals. The cores were then cemented back into their original position on the same day using quick-setting cement (Flashcrete, Lafargue Fondu). A previous study showed that this method had no immediate visible effects on the turf itself but removed approximately $90 \%$ of all animals, except bivalves (Kelaher 2000). Only about $60 \%$ of bivalves (mostly Lasaea australis) were removed because they are often embedded in the holdfasts of coralline turf, and it is not possible to remove them without destroying the turf itself. Some epiphytes were accidentally removed in the defaunating process but appeared to recover quickly. Because drilling and concreting rock cores could potentially be a large disturbance to macrofauna, which might itself alter the colonising assemblage, a procedural control was included in which rock cores were drilled and cemented back into position on the same day, but the turf was not defaunated. The experiment therefore had 4 treatments: untouched turf, artificial turf, defaunated turf and a procedural control.

For each treatment, 10 replicate patches were set up in December 1997. Patches of artificial turf, rock cores and samples of natural coralline turf were all $15 \mathrm{~cm}$ in diameter $\left(177 \mathrm{~cm}^{2}\right)$. This size of replicate was used because it provided reasonably precise estimates of the mean richness and abundances of taxa in this diverse macrofaunal assemblage (Kelaher 2000). The position of each replicate on the shore was haphazardly selected and measured relative to fixed markers. Five replicates of each treatment were to be destructively sampled 2 mo and 4 mo after the experiment was started. Over the course of the experiment, several patches of artificial turf and rock cores were severely damaged during storms. Consequently, the number of replicates for each treatment was reduced from 5 to 4 . For treatments with natural coralline turf, the sediment and algae in each replicate were scraped off at the level of the rock. Patches of artificial turf were simply unscrewed from the rock surface.
In the laboratory, each replicate of natural and artificial turf was washed thoroughly in a $500 \mu \mathrm{m}$ sieve. The fauna remaining in the sieve were identified and counted using a binocular microscope $(\times 16$ magnification). Although sessile animals that were permanently attached to the fronds or substrata (e.g. sponges, bryozoans, serpulid and spirorbid polychaetes, barnacles, etc.) were commonly found in the turf, these animals were not included in the study because the methods used were not appropriate to quantify them accurately. In total, 39320 individual animals were counted and identified in 102 different taxa (Table 1). The taxonomic resolution of macrofauna varied among groups because many of the animals were juveniles and could not be reliably identified to species using taxonomic keys (when keys were available), and many of the species have not been described in Australia.

Non-parametric multivariate analysis of variance (NP-MANOVA) were used to test hypotheses about differences among the composition of macrofaunal assemblages (Anderson 2001). NP-MANOVA were followed by a posteriori pair-wise comparisons on appropriate terms in the model found to be significant at $\mathrm{p} \leq 0.05$. For these tests, only probability values are presented because the multivariate $F$-statistics and $T$ statistics are generated by permutations. Non-metric multidimensional scaling (nMDS; Field et al. 1982, Clarke 1993) was used to produce 2-dimensional ordination plots to show relationships among samples of macrofaunal assemblages. All multivariate analyses were done using a Bray-Curtis similarity coefficient

Table 1. Summary of the 102 macrofanual taxa found in coralline turf during this study

\begin{tabular}{|lll|}
\hline Phylum & Class & $\begin{array}{l}\text { Number of taxa } \\
\text { and resolution }\end{array}$ \\
\hline $\begin{array}{l}\text { Cnidaria } \\
\text { Platyhelminthes }\end{array}$ & Anthozoa & 1 taxon \\
Nematoda & Turbellaria & 1 taxon \\
Nemertea & - & 1 taxon \\
Annelida & - & 1 taxon \\
& Oligochaeta & 1 taxon \\
Sipuncula & Polychaeta & 15 families \\
Arthropoda & - & 1 taxon \\
& Insecta & 2 species \\
& Pycnogonida & 1 taxon \\
& Arachnida & 1 taxon \\
& Ostracoda & 1 taxon \\
Mollusca & Copepoda & 1 taxon \\
& Malacostraca & 21 families \\
& Polyplacophora & 3 species \\
Echinodermata & Gastropoda & 41 species \\
& Bivalvia & 7 species \\
& Asteroidea & 1 species \\
Ophiuroidea & 1 taxon \\
atwelve of these in the order Amphipoda & 1 species \\
& & \\
\hline
\end{tabular}



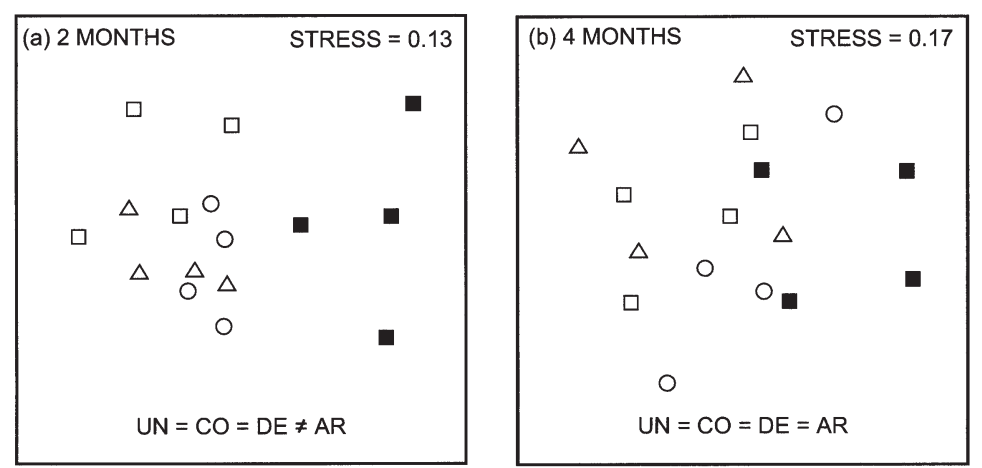

Fig. 1. Two-dimensional non-metric multidimensional scaling (nMDS) ordinations comparing macrofaunal assemblages in the untouched turf $(\mathrm{O}, \mathrm{UN})$, procedural control $(\triangle, \mathrm{CO})$, defaunated turf ( $\square, \mathrm{DE})$ and artificial turf $(\boldsymbol{\square}, \mathrm{AR})$ after (a) 2 and (b) 4 mo. For interpretation of post-hoc comparisons: $=, \mathrm{p}>0.05 ; \neq, \mathrm{p}<0.05$
(Bray \& Curtis 1957) on presence/absence data. Hypotheses were therefore tested about differences in the composition of assemblages because the abundances of individual taxa did not contribute to dissimilarity measures. Differences in abundances of individual taxa were subsequently tested with univariate analyses.

ANOVA was used to test hypotheses about differences in richness of taxa and abundances of nematodes, polychaetes, amphipods, gastropods and bivalves. The abundances of these faunal groups were analysed separately because they were generally the most diverse and abundant groups in the assemblage. ANOVA were preceded by Cochran's test for homogeneity of variances (Underwood 1997). Where variances showed significant heterogeneity, the data were transformed using a $\sqrt{X+1}$ function (Underwood 1997). After this, all Cochran's tests were not significant.

\section{RESULTS}

Two months after the experiment was started, the composition of macrofaunal assemblages in artificial turf was significantly different from that of the other treatments, which did not differ from each other (Fig. 1). Two months later, there were, however, no interpretable differences in the composition of macrofaunal assemblages among treatments (Fig. 1b; NPMANOVA: time $\times$ treatment interaction; $\mathrm{df}=3,24$; $p<0.05)$. Because at either time of sampling, there were no significant differences in the richness of taxa among treatments (Table 2, Fig. 2a), the differences in the composition of assemblages after 2 mo were mostly caused by differences in the identity of taxa and the frequency with which taxa occur in natural and artificial turf. For example, some taxa, such as polynoid polychaetes, podocorid amphipods and the snail Austrocochlea porcata, were found in artificial turf after

Table 2. ANOVA for richness of taxa and abundances of major faunal groups ( $\mathrm{n}=4$ replicate cores in each treatment). ti: fixed comparsion between abundances at 2 and 4 months; tr: fixed comparsion among the 4 treatments; ${ }^{*} \mathrm{p}<0.05 ;{ }^{* *} \mathrm{p}<0.01$; ${ }^{* * *} \mathrm{p}<0.001$; ns: $\mathrm{p}>0.05$. See Fig. 2 for interpretation of Student-Neuman-Keuls tests

\begin{tabular}{|c|c|c|c|c|c|c|c|}
\hline & & \multicolumn{2}{|c|}{ (a) Taxonomic richness } & \multicolumn{2}{|c|}{ (b) Nematoda } & \multicolumn{2}{|c|}{ (c) Amphipods } \\
\hline \multirow{2}{*}{ Transform } & & \multicolumn{2}{|c|}{ None } & \multicolumn{2}{|c|}{$\sqrt{X+1}$} & \multicolumn{2}{|c|}{ None } \\
\hline & $\mathrm{df}$ & MS & $F$ & MS & $F$ & MS & $F$ \\
\hline Times (ti) & 1 & 12.50 & $0.78 \mathrm{~ns}$ & 3.79 & $1.26 \mathrm{~ns}$ & 144991.12 & $33.95^{* * *}$ \\
\hline Treatment (tr) & 3 & 16.45 & $1.02 \mathrm{~ns}$ & 24.29 & $8.08^{* *}$ & 18288.79 & $4.28^{*}$ \\
\hline $\mathrm{ti} \times \operatorname{tr}$ & 3 & 49.83 & $3.10^{*}$ & 11.66 & $3.88^{*}$ & 19790.79 & $4.63^{*}$ \\
\hline \multirow[t]{2}{*}{ Residual } & 24 & 16.06 & & 3.00 & & 4270.58 & \\
\hline & & \multicolumn{2}{|c|}{ (d) Polychaetes } & \multicolumn{2}{|c|}{ (e) Gastropods } & \multicolumn{2}{|c|}{ (f) Bivalves } \\
\hline \multirow[t]{2}{*}{ Transform } & & \multicolumn{2}{|c|}{$\sqrt{X+1}$} & \multicolumn{2}{|c|}{$\sqrt{X+1}$} & \multicolumn{2}{|c|}{ None } \\
\hline & $\mathrm{df}$ & MS & $F$ & MS & $F$ & MS & $F$ \\
\hline Times (ti) & 1 & 0.68 & $0.11 \mathrm{~ns}$ & 384.73 & $57.08^{* * *}$ & 21840.50 & $0.57 \mathrm{~ns}$ \\
\hline Treatment (tr) & 3 & 6.36 & $0.99 \mathrm{~ns}$ & 11.61 & $1.72 \mathrm{~ns}$ & 219300.41 & $5.75^{* *}$ \\
\hline $\operatorname{ti} \times \operatorname{tr}$ & 3 & 10.29 & $1.61 \mathrm{~ns}$ & 55.16 & $8.18^{* * *}$ & 272450.75 & $7.14^{* * *}$ \\
\hline Residual & 24 & 6.40 & & 6.73 & & 38144.91 & \\
\hline
\end{tabular}


2 mo but were not in coralline turf. In contrast, other taxa, such as the dipteran larvae Clunio sp., the starfish Patiriella exigua and pycnogonids, were found in natural coralline turf but not in artificial turf. Furthermore, some taxa, such as polyclad flat worms $\chi^{2}=$ 8.89, $1 \mathrm{df}, \mathrm{p}<0.01)$ and the snail Littorina acutispira $\left(\chi^{2}=4.45,1 \mathrm{df}, \mathrm{p}<0.05\right)$, occurred more frequently in replicates of artificial turf than in natural turf. Other taxa, such as the snails Zafra atkinsoni $\left(\chi^{2}=10.00,1 \mathrm{df}\right.$, $\mathrm{p}<0.01)$ and Rissoella confusa robertsoni $\left(\chi^{2}=8.89\right.$, $1 \mathrm{df}, \mathrm{p}<0.01$ ), showed completely opposite patterns of occurrence. Despite differences in early colonisation, however, the compositions of assemblages in coralline and artificial turf were similar after $4 \mathrm{mo}$. Moreover, all of the taxa found in artificial turf have been found in coralline turf at various times and places (Kelaher 2000).

The abundance of polychaetes did not differ significantly among treatments at either time of sampling (Table 2, Fig. 2b). After 2 mo, however, there were significantly more nematodes in the untouched treatment than in other treatments (Table 2, Fig. 2c), which indicates that nematodes had not yet fully colonised the defaunated artificial treatments or that drilling and concreting rock cores had short-term negative effects on these animals. After $4 \mathrm{mo}$, the abundance of nematodes did not differ significantly among treatments (Fig. 2c). Amphipods exhibited a different pattern of colonisation because, although the abundance of amphipods did not significantly differ among treatments after $2 \mathrm{mo}$, there were significantly more amphipods in the artificial turf than in the other treatments after 4 mo (Table 2, Fig. 2d). In contrast to other taxa, after $2 \mathrm{mo}$, there were significantly more gastropods and bivalves in the untouched and control treatments than in the defaunated and natural treatments (Table 2, Fig. 2e,f). This indicates that 2 mo was not enough time for these molluscs to fully colonise defaunated turf. After $4 \mathrm{mo}$, the abundance of gastropods did not significantly vary among treatments (Fig. 2e), although there were more bivalves in the artificial turf than in other treatments (Fig. 2f).

\section{DISCUSSION}

It was predicted that the physical characteristics of coralline turf were mostly responsible for structuring associated macrofaunal assemblages, if the composition, richness and abundance of macrofauna in artificial turf converged over time to become similar to those in natural coralline turf. In analyses, this biological hypothesis was equivalent to the statistical null hypothesis. It is well known that failure to reject the (a) TAXONOMIC RICHNESS

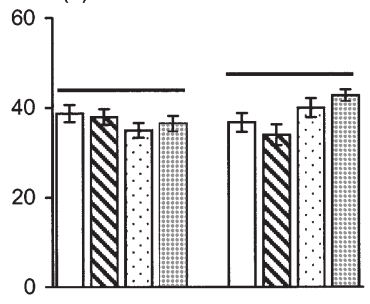

(c) NEMATODES

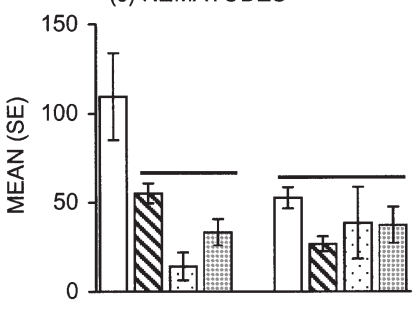

(e) GASTROPODS

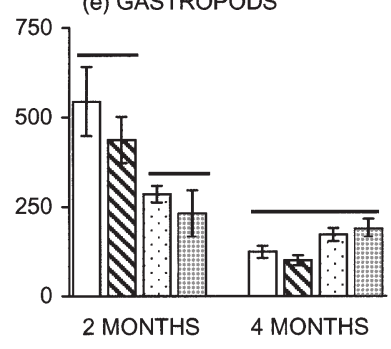

(b) POLYCHAETES

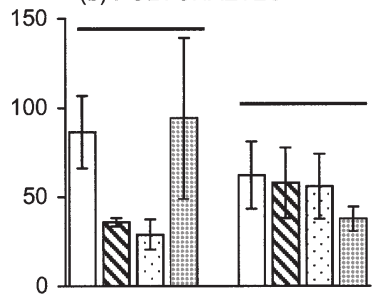

(d) AMPHIPODS

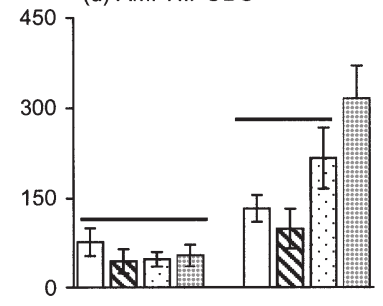

(f) BIVALVES

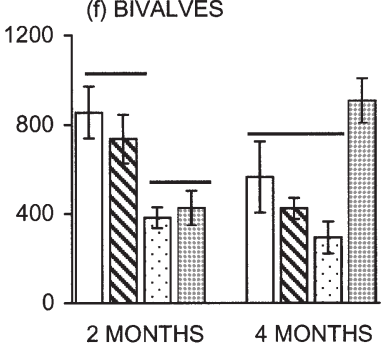

Fig. 2. Mean $( \pm \mathrm{SE})$ richness of taxa and abundances of main faunal groups in the untouched turf (white bars), procedural control (hashed bars), defaunated turf (dotted bars) and artificial turf (grey bars). For interpretations of Student-NewmanKeuls (SNK) tests: the line indicates no significant differences between treatments ( $p>0.05)$, and treatments with different lines or no line are significantly different $(\mathrm{p}<0.05)$

statistical null hypothesis is not considered proof that the null hypothesis is true because large variation among replicates and inadequate replication could be responsible (McDonald \& Erickson 1994). Prior information indicated that the size of replicate used in this study provided reasonably precise estimates of mean richness and abundance of macrofauna in coralline turf, reducing the chance of a Type II error (Kelaher 2000). Subsequently, the variation among replicates and interpretation of results of most comparisons in this study was completely reasonable. Nevertheless, caution was needed to interpret comparisons where there were large, but not significant, differences among treatment means and relatively large standard errors, e.g. abundances of polychaetes after 2 mo.

There was almost no evidence to suggest that the biological history of existing assemblages in coralline turf has lasting effects because, after $4 \mathrm{mo}$, there were no significant differences between the macrofauna in the untouched and those in the defaunated treatments. 
Including the defaunated treatment in the experiment was essential to interpret any differences between assemblages in natural and artificial turf in terms of artefacts associated with the artificial habitat or biological characteristics of coralline turf, rather than the result of processes that affected the assemblages before the experiment was set up. It is important that this type of control be considered in future experiments that use habitat mimics to test hypotheses about the effects of physical or biological characteristics of biogenic habitats.

Overall, the results show that the physical structure of coralline turf is extremely important to associated macrofaunal assemblages. Similar to other studies that have investigated the influence of physical characteristics of algal turf on macrofauna (e.g. Myers \& Southgate 1980, Edgar 1991) the present study did, however, also show that the physical structure of the habitat probably cannot explain the abundances of some taxa. In addition, after 2 mo, the differences between the compositions of macrofaunal assemblages in treatments with natural coralline turf and those in artificial turf probably indicate that the physical structure of coralline turf cannot completely explain the biodiversity of developing assemblages.

Although it is possible that the materials and structure of artificial turf cause differences between assemblages in natural and those in artificial turf, it is probable that biological characteristics of coralline turf make a major contribution to these differences. For example, differences between the composition of developing assemblages associated with coralline and artificial turf may be due to existing epiphytic algae and films of diatoms that were initially present on the natural coralline turf but not on the artificial turf. Each of these biological materials and the coralline turf itself provide a source of food for some animals (Worthington \& Fairweather 1989, Brawley 1992) and exude chemicals that may attract or repel larvae of marine invertebrates (see Underwood 1979, Pawlik 1990 for reviews) and, therefore, may influence the initial development of macrofaunal assemblages. Because there was much less difference in the composition of assemblages in natural and artificial turf after $4 \mathrm{mo}$, it is unlikely that any such initial differences have any lasting influences. It should be noted, however, that given longer time for colonisation, it is possible that composition of assemblages in the natural and artificial habitat could once again diverge.

One particularly striking difference between macrofauna in natural and those in artificial turf was the larger abundance of bivalves and amphipods in the artificial turf after 4 mo. Other studies using artificial habitat mimics to investigate the influence of habitat structure on marine macrofaunal assemblages have also found greater abundances of molluscs, small mobile crustaceans and other taxa in artificial habitat mimics than in natural habitats (marine algae, Myers \& Southgate 1980, Edgar 1991; seagrass, Virnstein \& Curran 1986; salt marsh, Cummings \& Ruber 1987), although possible mechanisms for these differences have rarely been discussed.

Because the artificial turf used in this study was not an exact mimic of natural coralline turf, it is possible that differences in abundances of macrofauna were caused by differences in physical structure. The biggest difference between the physical structure of natural and that of artificial turf is the complexity of individual fronds. Fronds of artificial turf have a relatively simple shape, whereas natural coralline turf has complex branching fronds. It has been shown that as the complexity of algal fronds increases, the diversity and abundance of the associated fauna also increase (Gee \& Warwick 1994, Davenport et al. 1999). In this study, there were, however, greater abundances of bivalves and amphipods in the habitat with simpler fronds. Consequently, differences between macrofaunal assemblages in natural and those in artificial turf are probably not related to differences in the structure of natural and artificial turfs but are due to biological characteristics of natural coralline turf.

One possible biological mechanism that may explain these differences is the continuous loss and growth of algal fronds that occur in natural turf. As natural algal fronds senesce and are removed from the turf, the epiphytes that are attached to them are also removed. Moreover, the extra drag created by epiphytes is likely to increase the rate of frond loss on relatively exposed rocky shores (D'Antonio 1985). The amount of epiphytes associated with algae and seagrass is often positively associated with the local abundance of amphipods (Schneider \& Mann 1991, Schreider 1998). Furthermore, small bivalves (especially Lasaea australis) are often weakly attached to algal fronds or wedged in the spaces between fronds and are therefore likely to be dislodged when fronds are removed. Because the fronds of artificial turf are rarely lost, it could therefore be expected that the abundances of amphipods and bivalves in developed assemblages would be greater in artificial turf than in natural coralline turf.

Previous studies have shown that the diversity and abundance of macrofauna often vary among patches of algal turf on rocky intertidal shores (e.g. Whorff et al. 1995, Kelaher 2000). The materials and techniques used in this experiment may be extremely useful for testing hypotheses about biological and environmental processes that cause such variation. First, the results showed that artificial grass made a reasonable surrogate for natural coralline turf. Artificial turf comes in a variety of physical structures (e.g. different lengths, 
widths and density of fronds) and therefore may be ideal for testing hypotheses about the influence of variation in habitat structure on the associated faunal assemblages. It is clear from the results of this study, however, that the timing of future experiments may be extremely important and should be specific to particular organisms being investigated. For example, experiments about bivalves should not exceed 2 mo because after this the abundances will deviate from those naturally found in coralline turf. Second, this study showed that it is possible to drill, cement and defaunate cores of rock with intact algal turf on top, with minimal disturbance to the turf itself. Transplantation experiments have been extremely useful for elucidating ecological processes on rocky intertidal shores (e.g. Schonbeck \& Norton 1980, Gunnill 1982). Such experiments have been rarely done on algal turf because of the difficulties involved in transplanting and re-establishing the algae. Using the techniques in this study, however, it should be possible to transplant algal turf with or without the associated macrofaunal assemblages to different places on the shore with relatively few artefacts.

In summary, this study demonstrated that, like other complex mat-like habitats on rocky shores, the physical structure of coralline turf is extremely important to the biodiversity of the associated macrofaunal assemblage. This is not unexpected because it is well known that the physical structure of these habitats may provide a refuge from desiccation (Nixon et al. 1971, Gibbons 1988), predation (Coull \& Wells 1983, Dean \& Connell 1987c) and wave action (Dommasnes 1968, Whorff et al. 1995). Nevertheless, there were clear differences in the abundance of some taxa between natural and artificial turf. Although it is possible that these differences were the results of artefacts associated with habitat mimics, it is probable that biological characteristics of coralline turf also influence the abundance of macrofauna in these habitats. To elucidate these processes, however, further experimentation is needed.

Acknowledgements. This study was part of a $\mathrm{PhD}$ supported by an Australian Post-Graduate Award and by funds from the Australian Research Council through the Centre for Research on Ecological Impacts of Coastal Cities. I thank my supervisors, Prof. A. J. Underwood and Dr. M. G. Chapman, for their help in various parts of this study. I am grateful to W. H. Wong and B. J. Allen for their helpful comments on earlier drafts of this manuscript.

\section{LITERATURE CITED}

Akioka H, Baba M, Masaki T, Johansen W (1999) Rocky shore turfs dominated by Corallina (Corallinales, Rhodophtya) in northern Japan. Phycol Res 47:199-206

Anderson MJ (2001) A new method for non-parametric multi- variate analysis of variance in ecology. Austral Ecol 26: $32-46$

Andre C, Rosenberg R (1991) Adult-larval interactions in the suspension-feeding bivalves Cerastoderma edule and Mya arenaria. Mar Ecol Prog Ser 71:227-234

Bell SS, McCoy ED, Mushinsky HR (1991) Habitat structure: the physical arrangements of objects in space. Chapman \& Hall, London

Brawley SH (1992) Mesoherbivores. In: John DM, Hawkins SJ, Price JH (eds) Plant-animal interactions in the marine benthos. Clarendon Press, Oxford, p 235-263

Bray JR, Curtis JT (1957) An ordination of the upland forest communities of southern Wisconsin. Ecol Monogr 27: 325-349

Brown PJ, Taylor RB (1999) Effects of trampling by humans on animals inhabiting coralline algal turf in the rocky intertidal. J Exp Mar Biol Ecol 235:45-53

Chapman MG, Underwood AJ (1998) Inconsistency and variation in the development of rocky intertidal algal assemblages. J Exp Mar Biol Ecol 224:265-289

Clarke KR (1993) Non-parametric analyses of changes in community structure. Aust J Ecol 18:117-143

Coull BC, Wells JB (1983) Refuges from fish predation: experiments with phytal meiofauna from the New Zealand rocky intertidal. Ecology 64:1599-1609

Crooks JA, Khim HS (1999) Architectural vs. biological effects of a habitat-altering exotic mussel, Musculista senhousia. J Exp Mar Biol Ecol 240:53-75

Cummings E, Ruber E (1987) Copepod colonization of natural and artificial substrates in a salt marsh pool. Estuar Coast Shelf Sci 25:637-645

D'Antonio C (1985) Epiphytes on the rocky intertidal red alga Rhodomela larix (Turner) C. Agardh: negative effects on the host and food for herbivores? J Exp Mar Biol Ecol 86: $197-218$

Davenport J, Butler A, Cheshire A (1999) Epifaunal composition and fractal dimensions of marine plants in relation to emersion. J Mar Biol Assoc UK 79:351-355

Dean RL, Connell JH (1987a) Marine invertebrates in algal succession. I. Variations in abundance and diversity with succession. J Exp Mar Biol Ecol 109:195-215

Dean RL, Connell JH (1987b) Marine invertebrates in algal succession. II. Tests of hypotheses to explain diversity with succession. J Exp Mar Biol Ecol 109:217-247

Dean RL, Connell JH (1987c) Marine invertebrates in algal succession. III. Mechanisms linking habitat complexity with diversity. J Exp Mar Biol Ecol 107:249-273

Dommasnes A (1968) Variations in the meiofauna of Corallina officinalis L. with wave exposure. Sarsia 34:117-124

Dye AH (1993) Recolonization of intertidal macroalgae in relation to gap size and molluscan herbivory on a rocky shore on the east coast of southern Africa. Mar Ecol Prog Ser 95:263-271

Edgar GJ (1991) Artificial algae as habitats for mobile epifauna: factors affecting colonization in a Japanese Sargassum bed. Hydrobiologia 226:111-118

Fairweather PG, Underwood AJ (1991) Experimental removals of a rocky intertidal predator: variations within two habitats in the effects on prey. J Exp Mar Biol Ecol 154:29-75

Field JG, Clarke KR, Warwick RM (1982) A practical strategy for analysing multispecies distribution patterns. Mar Ecol Prog Ser 8:37-52

Fielding PJ, Weerts KA, Forbes AT (1994) Macroinvertebrate community associated with intertidal and subtidal beds of Pyura stolonifera (Heller)(Tunicata: Ascidiacea) on the Natal coast. S Afr J Zool 29:46-53 
Gee JM, Warwick RM (1994) Metazoan community structure in relation to the fractal dimensions of marine macroalgae. Mar Ecol Prog Ser 103:141-150

Gibbons MJ (1988) The impact of sediment accumulations, relative habitat complexity and elevation on rocky shore meiofauna. J Exp Mar Biol Ecol 122:225-241

Gunnill FC (1982) Macroalgae as habitat patch islands for Scutellidiu, lamellipes (Copepoda: Harpacticoida) and Ampithoe tea (Amphipoda: Gammaridae). Mar Biol 69: 103-116

Healy B (1996) The distribution of Oligocheata on an exposed rocky shore in southeast Ireland. Hydrobiologia 334:51-62

Hicks GRF (1971) Check list and ecological notes on the fauna associated with some littoral corallinacean algae. Bull Nat Sci 2:47-58

Jones CG, Lawton JH, Shachak M (1994) Organisms as ecosystem engineers. Oikos 69:373-386

Jones CG, Lawton JH, Shachak M (1997) Positive and negative effects of organisms as physical ecosystem engineers. Ecology 78:1946-1957

Kelaher B (2000) Biodiversity of macrofaunal assemblages in coralline algal turf. $\mathrm{PhD}$ thesis, University of Sydney

Knowles LL, Bell SS (1998) The influence of habitat structure in faunal-habitat associations in a Tampa Bay seagrass system, Florida. Bull Mar Sci 62:781-794

McDonald LL, Erickson WP (1994) Testing for bioequivalence in field studies: has a disturbed site been adequately reclaimed? In: Fletcher DJ, Manly BJ (eds) Statistics in ecology and environmental monitoring. University of Otago Press, Dunedin, p 183-197

Myers AA, Southgate T (1980) Artificial substrates as a means of monitoring rocky shore cryptofuana. J Mar Biol Assoc UK 60:963-975

Nixon SW, Oviatt CA, Rodgers C, Taylor RK (1971) Mass and metabolism of a mussel bed. Oecologia 8:21-30

Pawlik JR (1990) Chemical ecology of the settlement of benthic marine invertebrates. Oceanogr Mar Biol Annu Rev 30:273-335

Schneider FI, Mann KH (1991) Species specific relationships of invertebrates to vegetation in a seagrass bed. I. Correlational studies. J Exp Mar Biol Ecol 145:101-117

Editorial responsibility: Roger Hughes (Contributing Editor), Bangor, Wales, UK
Schonbeck MW, Norton TA (1980) Factors controlling the lower limits of fucoid algae on the shore. J Exp Mar Biol Ecol 43:131-150

Schreider MJ (1998) Ecology of epifaunal crustaceans on intertidal algae. PhD thesis, University of Sydney

Seed R (1996) Patterns of biodiversity in the macro-invertebrate fauna associated with mussel patches on rocky shores. J Mar Biol Assoc UK 76:203-210

Sogard (1989) Colonisation of artificial seagrass by fishes and decapod crustaceans: importance of proximity to natural eelgrass. J Exp Mar Biol Ecol 133:15-37

Stewart JG (1982) Anchor species and epiphytes in intertidal algal turf. Pac Sci 36:45-59

Tsuchiya M, Nishihira M (1985) Islands of Mytilus edulis as a habitat for small intertidal animals: effect of island size on community structure. Mar Ecol Prog Ser 25:71-81

Underwood AJ (1979) The ecology of intertidal gastropods. Adv Mar Biol 16:111-210

Underwood AJ (1997) Experiments in ecology: their logical design and interpretation using analysis of variance. Cambridge University Press, Cambridge

Underwood AJ, Denley EJ, Moran MJ (1983) Experimental analyses of the structure and dynamics of mid-shore rocky intertidal communities in New South Wales. Oecologia 56: 202-219

Virnstein RW, Curran MC (1986) Colonization of artificial seagrass versus time and distance from source. Mar Ecol Prog Ser 29:279-288

Whorff JS, Whorff LL, Sweet MH (1995) Spatial variation in an algal turf community with respect to substratum slope and wave height. J Mar Biol Assoc UK 75:429-444

Williams GA, Seed R (1992) Interactions between macrofaunal epiphtyes and their host algae. In: John DM, Hawkins SJ, Price JH (eds) Plant-animal interactions in the marine benthos. Clarendon Press, Oxford, p 189-211

Williams JG (1980) The influence of adults on the settlement of spat of the clam, Tapes japonica. J Mar Res 38:729-751

Worthington DG, Fairweather PG (1989) Shelter and food: interactions between Turbo undulatum (Archaeogastropoda: Turbinidae) and coralline algae on rocky seashores in New South Wales. J Exp Mar Biol Ecol 129: $61-79$

Submitted: August 20, 2001; Accepted: November 19, 2001 Proofs received from author(s): April 10, 2002 